\title{
Mutagenic Effectiveness and Efficiency of Gamma ( $($ ) Rays and Ethyl Methane Sulphonate on Bougainvillea spectabilis Willd. (cv. Lalbagh)
}

\author{
K. Anitha ${ }^{1^{*}}$, R. Surendranath ${ }^{2}$, M. Jawaharlal ${ }^{3}$ and M. Ganga ${ }^{4}$ \\ ${ }^{1,2,4}$ Dept. of Floriculture and Landscaping, Faculty of Horticulture, ${ }^{3}$ Horticultural College and Research Institute (Women), \\ Trichy, Tamil Nadu Agricultural University, Coimbatore, Tamil Nadu (641 003), India
}

Corresponding Author

\begin{tabular}{l}
\hline K. Anitha \\
e-mail: anithasujay@gmail.com
\end{tabular}

\author{
Article History \\ Manuscript No. AR1634 \\ Received in $4^{\text {th }} \mathrm{Jul}, 2016$ \\ Received in revised form $10^{\text {th }}$ February, 2016 \\ Accepted in final form $6^{\text {th }}$ April, 2017
}

\begin{abstract}
Mutation breeding is an established method used for crop improvement and has played a major role in the development of many new flower colour shape mutant cultivars in ornamentals. The present study was undertaken to induce mutations in Bougainvillea spectabilis Willd. cv. Lalbagh using a physical mutagen ( $>$ rays) and a chemical mutagen (Ethyl Methane Sulphonate) for creating novelty during 2014-15 at TNAU, Coimbatore, Tamilnadu, India. Hardwood cuttings were treated with three doses of $\gamma$-rays (5.0, 7.5, 10.0 Gy) and three concentrations of Ethyl Methane Sulphonate $(0.8,0.9$ and $1.0 \%)$. The first mutant-vegetative $\left(M_{1} V_{1}\right)$ generation was evaluated for various morphological traits. Sprouting percentage and survival rate of seedlings gradually reduced with proportional increase in dose concentration of mutagens. All the morphological traits recorded a declining trend with increasing mutagenic treatments. Some of the morphological mutants' viz., dwarfness, early flowering and thornless stem were noticed within the mutagen treated plant population. Nine different types of chlorophyll mutants were observed namely albina, albina green, xantha, chlorina, viridis, yellow viridis, striata, maculata and variegated type. Among the chlorophyll mutants recorded, chlorina was more predominant followed by maculata and viridis. With regard to mutagenic treatments, EMS 1.0\% recorded more number of morphological mutants (12 Nos.) and chlorophyll mutants (20 Nos.). The 5.0 Gy dosage of $\gamma$-radiation recorded the highest mutagenic effectiveness (215.20) and efficiency (122.69) than other treatments. The highest mutation rates in terms of effectiveness (161.81) and efficiency (75.62) were recorded in EMS than -radiation in Bougainvillea cv. Lalbagh.
\end{abstract}

Keywords: Bougainvillea, mutagens, mutation, mutant-vegetative generation, mutagenic effectiveness

\section{Introduction}

Bougainvillea is a popular ornamental plant in tropical and sub-tropical gardens of the world. The colourful bracts and wide adaptability of Bougainvillea into different agro-climatic conditions are the main reasons for its popularity. Being a popular plant in horticultural nursery trade and grown in all types of gardens, greater variation in its colour, size and form would be of more use. In attempts to induce useful phenotypic variation in plants, mutagenic treatments have been used for many years. Spontaneous and induced mutations in plants contribute for genetic dissection of the function of wild type genes. The genetic variability present in any crop is of vital importance in the formulation of effective breeding program. Thus, the genetic variability generated by induced mutations can certainly help to recover the alleles for higher productivity and also for better plant type. The utilization of induced mutations for the improvement of crop plants has yielded several mutants which have been used directly as new cultivars (Gottschalk and Wolf, 1983). Among all the varieties developed through mutation breeding in India, 18\% were developed by altering plant type (Jain, 2010).

\section{Materials and Methods}

The experiment was conducted at the Department of Floriculture and Landscaping, Horticultural College and Research Institute, Tamil Nadu Agricultural University, Coimbatore, Tamil Nadu, India during 2014-15 to evaluate the effect of different doses of $\gamma$-rays and Ethyl Methane Sulphonate (EMS) on sprouting, survival and growth performance of Bougainvillea. Based on the lethal dose of Lalbagh cultivar, three treatments for each mutagen have been employed for the population of $\mathrm{M}_{1} \mathrm{~V}_{1}$ generation. Around 300 hardwood cuttings were used as biological material in each treatment.

\section{1. $\gamma$-irradiation}

Three radiation doses viz., 5.0, 7.5 and 10.0 Gy were used to treat the hardwood cuttings along with the untreated cuttings as control. $\gamma$-irradiation was given using ${ }^{60} \mathrm{Co} \gamma$-source 
(8-Chamber 1200, Board of Radiation and Isotope Technology (BRIT), Mumbai, India) at Centre for Plant Breeding and Genetics, Tamil Nadu Agricultural University, Coimbatore, Tamil Nadu, India.

\subsection{EMS treatment}

In case of EMS treatment, three different concentrations viz., $0.8,0.9$ and $1.0 \%$ were utilized and water soaked (10 hrs) cuttings were used as control. The hardwood cuttings were presoaked in water for $4 \mathrm{hrs}$ to enhance the imbibitions capacity of the tissues to absorb the EMS. After shade drying of the water soaked cuttings, they were soaked in freshly prepared EMS solution for 6 hrs. Then the cuttings were thoroughly washed with water for one hour to remove the chemical residues.

The mutagen treated hardwood cuttings were planted in polybags containing potting mixture comprising of red soil, sand, leaf mould and Farm Yard Manure in the ratio of 1:1:1:1 and kept under mist chamber to enhance rooting. The population was observed for sprouting at 45 days after planting (DAP), survival (60 and 120 DAP) and other morphological characters. The mean values for the characters studied were calculated for each treatment and expressed as percentage reduction over the control.

The $M_{1} V_{1}$ population was screened for spectrum of morphological and chlorophyll mutations. The chlorophyll mutants were classified as the scheme of Gustafson (1940) and Blixt (1972). The formulae proposed by Konzak et al. (1965) were followed for calculating mutagenic effectiveness and efficiency by incorporating the mutation frequency values recorded for each mutagenic treatment.

\begin{tabular}{|c|c|}
\hline \multirow{2}{*}{ Mutagenic effectiveness= } & Mutagenic frequency \\
\hline & Dose or (Concentration $\times$ time) \\
\hline \multirow{2}{*}{ Mutagenic efficiency= } & Mutagenic frequency \\
\hline & Biological damage \\
\hline
\end{tabular}

Mutation rate (MR) provides the knowledge of mutations induced by a particular mutagen irrespective of dose or concentration.

$$
\begin{gathered}
\begin{array}{c}
\text { Sum of values of efficiency or } \\
\text { effectiveness of particular mutagen }
\end{array} \\
\text { Mutation rate }=\text { No. of treatments of a particular mutagen }
\end{gathered}
$$

\section{Results and Discussion}

Gaul (1970) reported that physical and chemical mutagens induce physiological damages (injury), gene mutations (point mutation) and chromosomal mutations (chromosomal aberration) of the biological material in $\mathrm{M}_{1}$ generation. The quantitative determination in $\mathrm{M}_{1}$ might enable to predict the efficiency of mutagens and identification of desirable mutants. Determination of $M_{1}$ injury using seedling height and survival is a routine procedure in mutation breeding, because it has been established that these characters are correlated with $M_{1}$ mutation frequency (Etsuo Amano, 2004). In $\mathrm{M}_{1}$ generation effect of mutagenic treatments were assessed on the basis of sprouting reduction (\%) against control.

In the present study, reduction in sprouting per cent and survival per cent (60 DAP \& 120 DAP) of treated cuttings were concentration dose dependent and linear (Table 1). Maximum sprouting of $95.0 \%$ and $96.67 \%$ were noticed in case of control with respect to $\gamma$-rays and EMS respectively. Among the treatments, 5.0 Gy of $\gamma$-irradiation and $0.8 \%$ of EMS recorded higher sprouting of $86.7 \%$ and $91.33 \%$ respectively. With respect to survival per cent (60 DAP \& 120 DAP), maximum of $93.67 \%$ and $90.67 \%$ were recorded in control in case of $\gamma$ -ray treatment, whereas $94.67 \%$ and $92.67 \%$ was recorded in control of EMS treatment during 60 DAP and 120 DAP respectively. Significant reduction in sprouting percentage as well as survival percentage was noticed after exposure

\begin{tabular}{|c|c|c|c|c|c|c|}
\hline \multirow{2}{*}{$\begin{array}{l}\text { Treat- } \\
\text { ment }\end{array}$} & \multirow[t]{2}{*}{$\mathrm{S}$} & \multirow[t]{2}{*}{ ROC } & \multicolumn{2}{|c|}{ (60 DAP) } & \multicolumn{2}{|c|}{ (120 DAP) } \\
\hline & & & $\begin{array}{c}\text { Sur } \\
\text { vival \% }\end{array}$ & ROC & $\begin{array}{c}\text { Sur } \\
\text { vival \% }\end{array}$ & ROC \\
\hline \multicolumn{7}{|c|}{ Physical mutagen (Gamma rays) } \\
\hline Control & 95.00 & - & 93.67 & - & 90.67 & - \\
\hline 5.0 (Gy) & 86.70 & 8.77 & 62.33 & 33.45 & 52.67 & 41.91 \\
\hline 7.5 (Gy) & 74.70 & 21.40 & 57.33 & 38.79 & 50.33 & 44.49 \\
\hline 10.0 (Gy) & 65.30 & 31.23 & 50.33 & 46.26 & 44.33 & 51.10 \\
\hline \multicolumn{7}{|c|}{ Chemical mutagen (EMS) } \\
\hline Control & 96.67 & & 94.67 & - & 92.67 & - \\
\hline $0.8(\%)$ & 91.33 & 5.52 & 73.33 & 22.54 & 67.67 & 26.98 \\
\hline $0.9(\%)$ & 83.67 & 13.45 & 65.33 & 30.99 & 63.00 & 32.01 \\
\hline $1.0(\%)$ & 77.33 & 20.00 & 59.67 & 36.97 & 54.00 & 41.73 \\
\hline
\end{tabular}

Table 1: Effect of mutagens on sprouting and survival percentage of Bougainvillea $\mathrm{cv}$. Lalbagh

S: Sprouting (\%); ROC: \% reduction over control;

to $\gamma$-rays. The same results were also reported by Datta and Banerji (1997) in four double bracted Bougainvillea cultivars and Gupta and Shukla (1974) in nine cultivars of Bougainvillea. Reduction in survival after exposure to $\gamma$-rays was explained as a consequence of inactivation and/or decrease in auxin content that affects cell division, which ultimately results in poor establishment and survival (Gordon, 1957; Mahure et al., 2010) or lethal effect of $\gamma$-rays caused due to chromosomal aberration (Datta and Banerji, 1993).

Dilta et al. (2003) reported that higher concentrations of EMS reduced the plant survival per cent in chrysanthemum. Misra and Bajpai (1983a) also observed up to $50 \%$ reduction in survival percentage of plants in gladiolus over control when treated with different chemical mutagens viz., EMS, DES and $\mathrm{MNH}$. The drastic reduction in plant survival may be due to the formation of certain toxic substances by some biochemical 
substances which cause death of the cells, ultimately resulting in the death of plants (Sax, 1955; D'Amato and Ostenhof, 1956; Gordon, 1956).

\subsection{Mean performance of growth related traits}

Data pertaining to response of various agronomical characters pertaining to applied doses of the two mutagens are represented in Table 2 . The data reveal differences among character values that fluctuate from treatment to treatment.

\begin{tabular}{|c|c|c|c|c|c|c|c|c|c|c|c|c|c|}
\hline \multirow{2}{*}{$\begin{array}{l}\text { Treat- } \\
\text { ment }\end{array}$} & \multicolumn{2}{|c|}{ SL } & \multicolumn{2}{|c|}{ IL } & \multicolumn{2}{|c|}{ NSC } & \multicolumn{2}{|c|}{ NL } & \multicolumn{2}{|c|}{$\mathrm{AL}$} & \multicolumn{2}{|c|}{ LCC } & \multirow{2}{*}{$\frac{\mathrm{LL}}{\text { Mean } \pm \mathrm{SE}}$} \\
\hline & $\begin{array}{c}\text { Mean } \\
\pm \text { SE }\end{array}$ & $\begin{array}{l}\text { CV. } \\
(\%)\end{array}$ & $\begin{array}{c}\text { Mean } \\
\pm \text { SE }\end{array}$ & $\begin{array}{l}\text { CV. } \\
(\%)\end{array}$ & $\begin{array}{c}\text { Mean } \\
\pm S E\end{array}$ & $\begin{array}{l}\text { CV. } \\
(\%)\end{array}$ & $\begin{array}{c}\text { Mean } \\
\pm \text { SE }\end{array}$ & $\begin{array}{l}\text { cV. } \\
(\%)\end{array}$ & $\begin{array}{c}\text { Mean } \\
\pm \text { SE }\end{array}$ & $\begin{array}{l}\text { CV. } \\
(\%)\end{array}$ & $\begin{array}{c}\text { Mean } \\
\pm \text { SE }\end{array}$ & $\begin{array}{l}\text { cV. } \\
(\%)\end{array}$ & \\
\hline \multicolumn{14}{|c|}{ Gamma rays (Gy) } \\
\hline Control & $\begin{array}{c}21.52 \pm \\
0.62\end{array}$ & 9.15 & $\begin{array}{c}1.76 \pm \\
0.14\end{array}$ & 25 & $\begin{array}{l}2.9 \pm \\
0.16\end{array}$ & 17.24 & $\begin{array}{c}24.1 \pm \\
0.97\end{array}$ & 12.66 & - & - & $\begin{array}{c}32.07 \pm \\
1.60\end{array}$ & 15.78 & $\begin{array}{c}4.95 \pm \\
0.22\end{array}$ \\
\hline 5.0 (Gy) & $\begin{array}{c}4.45 \pm \\
0.56\end{array}$ & 108.31 & $\begin{array}{c}1.22 \pm \\
0.06\end{array}$ & 42.62 & $\begin{array}{c}1.63 \pm \\
0.08\end{array}$ & 42.33 & $\begin{array}{c}8.85 \pm \\
0.55\end{array}$ & 53.9 & $\begin{array}{c}29.82 \pm \\
2.88\end{array}$ & 83.53 & $\begin{array}{c}27.97 \pm \\
0.84\end{array}$ & 26.06 & $\begin{array}{c}4.31 \pm \\
0.13\end{array}$ \\
\hline 7.5 (Gy) & $\begin{array}{c}1.28 \pm \\
0.18\end{array}$ & 157.81 & $\begin{array}{c}1.26 \pm \\
0.05\end{array}$ & 43.65 & $\begin{array}{c}1.61 \pm \\
0.06\end{array}$ & 39.75 & $\begin{array}{c}5.92 \pm \\
0.27\end{array}$ & 53.04 & $\begin{array}{c}43.94 \pm \\
1.87\end{array}$ & 49.09 & $\begin{array}{c}32.04 \pm \\
0.60\end{array}$ & 21.57 & $\begin{array}{c}3.58 \pm \\
0.09\end{array}$ \\
\hline 10.0 (Gy) & $\begin{array}{c}5.81 \pm \\
0.44\end{array}$ & 91.05 & $\begin{array}{c}1.34 \pm \\
0.05\end{array}$ & 44.78 & $\begin{array}{c}1.59 \pm \\
0.05\end{array}$ & 37.74 & $\begin{array}{c}11.72 \pm \\
0.57\end{array}$ & 57.51 & $\begin{array}{c}53.05 \pm \\
2.22\end{array}$ & 49.92 & $\begin{array}{c}37.89 \pm \\
0.51\end{array}$ & 16.15 & $\begin{array}{c}3.63 \pm \\
0.08\end{array}$ \\
\hline \multicolumn{14}{|c|}{ Ethyl methane sulphonate (\%) } \\
\hline Control & $\begin{array}{c}24.95 \pm \\
0.81\end{array}$ & 10.3 & $\begin{array}{c}1.61 \pm \\
0.09\end{array}$ & 18.63 & $\begin{array}{c}3.10 \pm \\
0.23\end{array}$ & 23.87 & $\begin{array}{c}34.9 \pm \\
2.21\end{array}$ & 20 & - & - & $\begin{array}{c}30.09 \pm \\
0.82\end{array}$ & 8.57 & $4.11 \pm 0.15$ \\
\hline $0.8 \%$ & $\begin{array}{c}11.39 \pm \\
0.80\end{array}$ & 61.55 & $\begin{array}{c}1.03 \pm \\
0.05\end{array}$ & 43.69 & $\begin{array}{c}2.43 \pm \\
0.13\end{array}$ & 45.27 & $\begin{array}{c}23.23 \pm \\
1.20\end{array}$ & 44.9 & $\begin{array}{c}37.15 \pm \\
2.37\end{array}$ & 55.56 & $\begin{array}{c}33.16 \pm \\
0.47\end{array}$ & 12.24 & $4.58 \pm 0.10$ \\
\hline $0.9 \%$ & $\begin{array}{l}8.97 \pm \\
0.66\end{array}$ & 72.58 & $\begin{array}{c}1.00 \pm \\
0.03\end{array}$ & 33 & $\begin{array}{c}2.45 \pm \\
0.08\end{array}$ & 31.02 & $\begin{array}{c}24.91 \pm \\
1.13\end{array}$ & 44.76 & $\begin{array}{c}32.67 \pm \\
1.25\end{array}$ & 37.99 & $\begin{array}{c}32.86 \pm \\
0.41\end{array}$ & 12.23 & $4.35 \pm 0.08$ \\
\hline $1.0 \%$ & $\begin{array}{l}7.47 \pm \\
0.61\end{array}$ & 80.99 & $\begin{array}{c}0.97 \pm \\
0.03\end{array}$ & 35.05 & $\begin{array}{c}2.50 \pm \\
0.10\end{array}$ & 39.6 & $\begin{array}{c}18.85 \pm \\
0.86\end{array}$ & 45.15 & $\begin{array}{c}37.49 \pm \\
1.35\end{array}$ & 35.66 & $\begin{array}{c}35.29 \pm \\
0.54\end{array}$ & 15.25 & $4.30 \pm 0.07$ \\
\hline
\end{tabular}

Table 2: Continue...

\begin{tabular}{|c|c|c|c|c|c|}
\hline \multirow{2}{*}{$\begin{array}{l}\text { Treat- } \\
\text { ment }\end{array}$} & \multirow{2}{*}{$\begin{array}{l}\mathrm{LL} \\
\mathrm{CV} . \\
(\%) \\
\end{array}$} & \multicolumn{2}{|l|}{ LW } & \multicolumn{2}{|l|}{ LT } \\
\hline & & $\begin{array}{l}\text { Mean } \\
\pm \text { SE }\end{array}$ & $\begin{array}{l}\text { CV. } \\
(\%)\end{array}$ & Mean \pm SE & $\begin{array}{l}\text { CV. } \\
(\%)\end{array}$ \\
\hline \multicolumn{6}{|c|}{ Gamma rays (Gy) } \\
\hline Control & 14.14 & $3.15 \pm 0.17$ & 16.83 & $0.290 \pm 0.02$ & 22.41 \\
\hline 5.0 (Gy) & 26.68 & $2.95 \pm 0.08$ & 24.41 & $0.371 \pm 0.01$ & 24.26 \\
\hline 7.5 (Gy) & 30.17 & $2.21 \pm 0.06$ & 29.41 & $0.359 \pm 0.01$ & 27.02 \\
\hline 10.0 (Gy) & 26.45 & $2.42 \pm 0.10$ & 47.11 & $0.366 \pm 0.01$ & 21.86 \\
\hline \multicolumn{6}{|c|}{ Ethyl methane sulphonate (\%) } \\
\hline Control & 11.92 & $2.87 \pm 0.10$ & 11.15 & $0.274 \pm 0.01$ & 16.79 \\
\hline $0.8 \%$ & 18.56 & $2.83 \pm 0.05$ & 16.25 & $0.378 \pm 0.01$ & 14.55 \\
\hline $0.9 \%$ & 17.47 & $2.61 \pm 0.05$ & 19.54 & $0.368 \pm 0.00$ & 11.96 \\
\hline $1.0 \%$ & 17.21 & $3.20 \pm 0.05$ & 16.25 & $0.430 \pm 0.01$ & 24.19 \\
\hline
\end{tabular}

SL: Shoot length $(\mathrm{cm})$; IL: Internodal length $(\mathrm{cm})$; NSC: Number of sprouts cutting ${ }^{-1}$; NL: Number of leaves; AL: Abnormal leaves (\%); LCC: Leaf Chlorophyll content $\left(\mathrm{mg} \mathrm{g}^{-1}\right)$; LL: Leaf length (cm); LW: Leaf width (cm); LT: Leaf thickness; CV: Coefficient of Variation; SE: Standard Error

It was observed that under all the treatments, values for most of the characters were decreasing with increasing concentration. The shoot length ranged from $1.28 \mathrm{~cm}(7.5 \mathrm{~Gy})$ to $5.81 \mathrm{~cm}(10.0 \mathrm{~Gy})$. Increase in shoot length was marginally higher at increased doses (10.0 Gy) compared to the lower doses of mutagenic treatment. Kainthura and Srivastava (2015) in tuberose and Ramesh et al. (2012) in mulberry also reported an increase in plant height with the increase in dose of mutagen to a certain optimum level of the mutagenic dose. Fowler and Mac Queen (1972) hypothesized that most of the reported stimulatory effects of low doses of radiation were due to early modifications in axillary bud development and changes in the initial rate of floral differentiation. In EMS treatments, there was a progressive and significant reduction in the values with increase in concentration thus indicating a negative shift. Among the two mutagens, $\gamma$-rays recorded lower shoot length than the EMS treatment. With respect to internodal length, there was a proportional increase noticed with increasing dose of $\gamma$-rays and it ranged from $1.22 \mathrm{~cm}$ (5.0 Gy) to $1.34 \mathrm{~cm}(10.0 \mathrm{~Gy})$ in $\gamma$-ray treatments, whereas it ranged from $0.97 \mathrm{~cm}(1.0 \%)$ to $1.03 \mathrm{~cm}(0.8 \%)$ in EMS treated cuttings, indicating a negative shift with increasing concentration. Among all the treatments, 1.0\% EMS recorded 
the lowest internodal length. There was not much difference recorded for number of sprouts among the $\gamma$-ray treatments. The same was noticed in EMS treatments also. But among all the treatments of these two mutagens, EMS recorded more number of sprouts than $\gamma$-irradiation.

The same trend in shoot length as well as number of sprouts were reported by Datta and Banerji (1997) and Gupta and Shukla (1974) in Bougainvillea cultivars. Reduction in vegetative characters by $\gamma$-ray treated plants depends on the nature and extent of chromosomal damage or due to physiological, morphological and cytological disturbance caused by irradiation (Banerji and Datta, 2002). Roychowdhury and Tah (2011) in carnation and Misra and Bajpai (1983b) in gladiolus recorded similar results with chemical mutagens and explained that chemical mutagens proved to be injurious as they promote physiological disturbance, retarded cell division by arresting the mitotic division and had ill-effect on auxin thereby resulting in reduction of morphological characters. Similar results were reported by Mekala (2009) for number of sprouts in jasmine and Padmadevi (2009) in chrysanthemum and Dhivya (2015) in Crossandra for length of internode.

Treatments with both physical and chemical mutagen have registered lesser number of leaves with increment in dose of mutagens which is in line with the findings of Roychowdhury and Tah (2011) in carnation. Vegetative abnormalities like variation in leaf shape, size, margin and apex fusion (Figure 1) increased significantly due to effect of different mutagenic treatments in Bougainvillea variety 'Lalbagh'. The frequency of
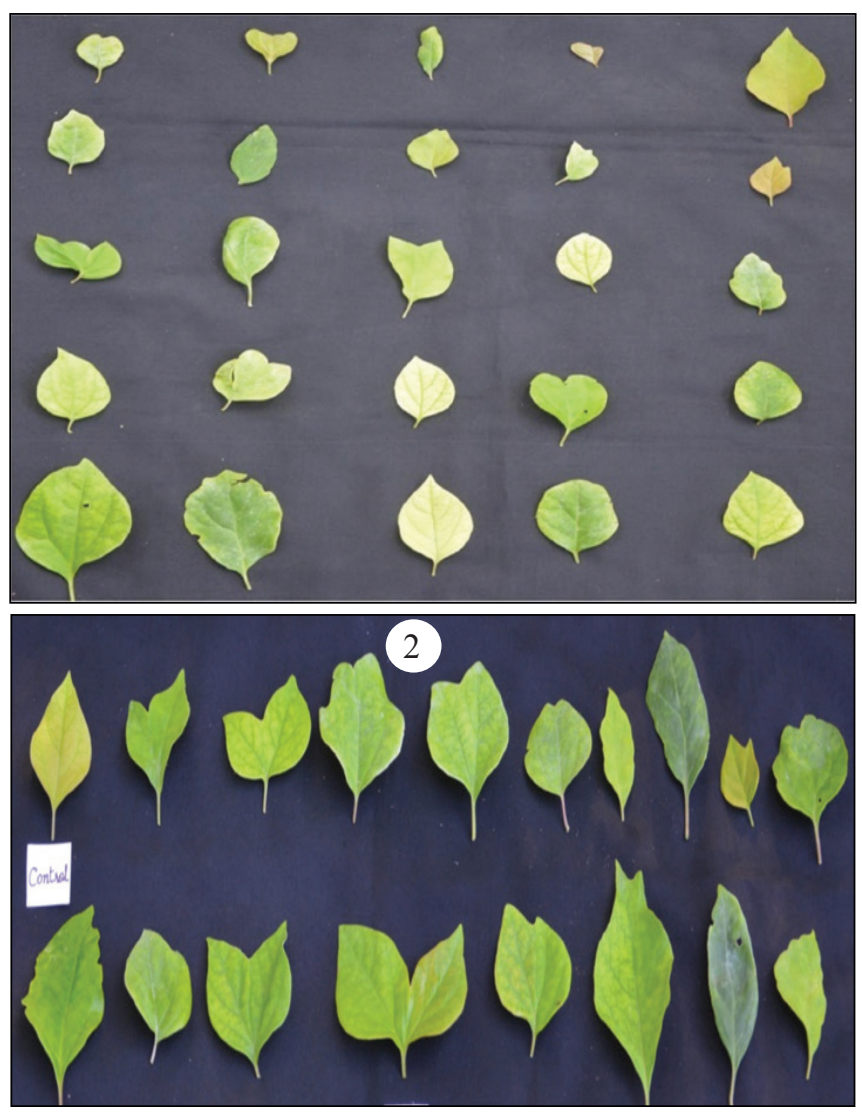

$\varnothing$
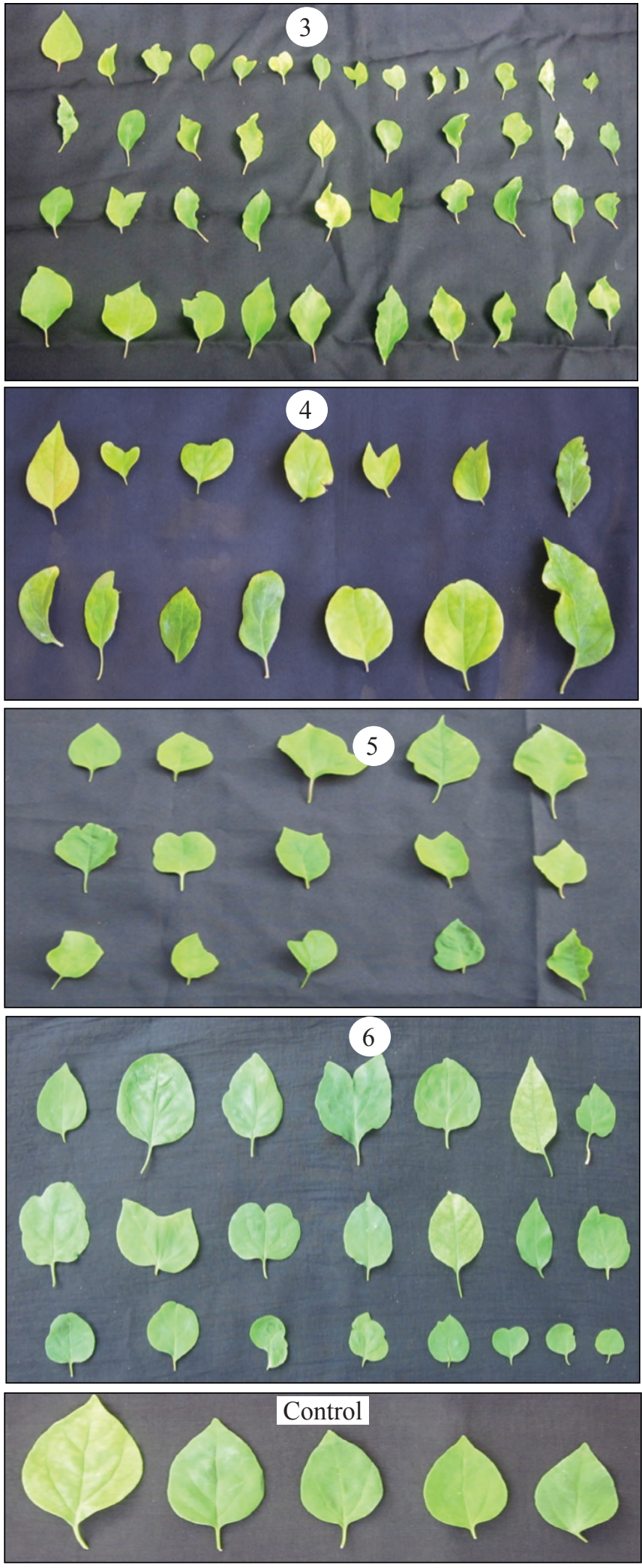

1: 5.0 Gy Gamma rays; 2:7.5 Gy Gamma rays; 3: 10.0 Gy Gamma rays; 4: 0.8\% EMS; 5: 0.9\% EMS; 6: 1.0\% EMS

Figure 1: Vegetative abnormalities observed with different mutagens in M1V1 generation of Bougainvillea cv. Lalbagh 
abnormalities increased with increase in doses of mutagens. Among all the treatments, $10.0 \mathrm{~Gy}$ of $\gamma$-radiation recorded the highest per cent (53.05\%) of abnormal leaves and 1.0\% EMS with $37.49 \%$ compared to other EMS concentrations. It may possibly be due to the inactivation and/or disturbances in the auxin synthesis (Gordon, 1957) and extent of chromosomal aberrations (Sparrow and Evan, 1961). Similar evidences have been documented in Bougainvillea by Datta and Banerji (1997), Gupta and Shukla (1974) and in chrysanthemum by Misra et al. (2009) and Kapadiya et al. (2014).

With respect to leaf length, both $\gamma$-ray treatments and EMS treatments recorded lesser values with increase in the dosage of mutagen. In $\gamma$-ray treatments, 5.0 Gy recorded the highest mean value of leaf length $(4.31 \mathrm{~cm})$, whereas in case of EMS, $0.8 \%$ recorded higher value of $4.58 \mathrm{~cm}$. All the mutagenic treatments exhibited gradual reduction in values for leaf width, except for $1.0 \%$ EMS, which recorded $3.20 \mathrm{~cm}$ which might be due to the mutagenic effect. Leaf thickness in all the mutagen treated population exhibited a positive shift with increase in dosage in both the mutagens. Kumari et al. (2013) reported reduction in leaf size in terms of length and width of plants treated with higher doses of $\gamma$-rays in chrysanthemum variety 'Otome Pink'.

\subsection{Variability in morphological traits}

Induced variability as measured by co-efficient of variation indicated highly significant differences between the treatments (Table 2). Coefficient of variation was highest at 7.5 Gy $\gamma$-rays than other treatments with respect to shoot length (157.81\%), leaf lenth and leaf thickness. Among all $\gamma$ -treatments $5.0 \mathrm{~Gy}$ recorded the highest variability for the traits number of sprouts $(42.33 \%)$ and abnormal leaves percentage with $83.53 \%$ of $\mathrm{CV}$. With respect to internodal length, number of leaves and leaf width, $10.0 \mathrm{~Gy}$ of 8 -radiation recorded highest co-efficient of variation with $44.78 \%$, $57.51 \%$ and $47.11 \%$ respectively when compared to other two treatments.

In case of EMS treated cuttings, $0.8 \%$ concentration had resulted in higher variations for many of the morphological characters viz., internodal length (43.69\%), number of sprouts (45.27\%), abnormal leaves percentage (55.56\%) and leaf length $(18.56 \%)$ than other concentrations.

With regard to shoot length and leaf thickness, 1.0\% EMS recorded higher variability of $80.99 \%$ and $24.19 \%$ respectively than other EMS treatments.

While considering all the treatments of the two mutagens, $\gamma$ -rays exhibited maximum variability for the traits observed. This was confirmed by the $c v$. percent recorded for all morphological characters which were comparatively higher than what was observed for control. Similar results were reported by Padmadevi (2009) in chrysanthemum and Mekala (2009) in jasmine for different growth related traits. Gregory (1966) postulated that shift in mean in many of the treated population was because of the differences in the magnitude of induced individual changes.

\subsection{Viable mutants}

Various kinds of morphological mutants' viz., dwarf mutant, early flowering mutant and thornless stem mutant have been recorded in $M_{1} V_{1}$ generation (Figure 2) with both physical and chemical mutagenic treatments. Among the treatments, 1.0\% EMS registered maximum (12) number of morphological mutants which included seven dwarf mutants and five thornless mutants (Table 3). Both 7.5 Gy and 10.0 Gy $\gamma$-rays recorded one early flowering mutant each. Padmadevi (2009) reported dwarf as well as early flowering mutants in chrysanthemum with different mutagenic treatments.

Table 3: Spectrum of morphological mutants in the M1V1 generation of Bougainvillea cv. Lalbagh

\begin{tabular}{lccccc}
\hline Treatment & NPO & NMM & \multicolumn{2}{c}{$\begin{array}{c}\text { Spectrum of morphological } \\
\text { mutants }\end{array}$} \\
\cline { 4 - 6 } & & & DM & EFM & TSM \\
\hline \multicolumn{2}{l}{ Gamma rays (Gy) } & & & & \\
\hline $5.0(G y)$ & 158 & 7 & 6 & 1 & - \\
7.5 (Gy) & 151 & 6 & 5 & 1 & - \\
10.0 (Gy) & 133 & 6 & 5 & 1 & - \\
Ethyl Methane Sulphonate (\%) & & & \\
\hline $0.8 \%$ & 203 & 2 & 2 & - & - \\
$0.9 \%$ & 189 & 3 & 3 & - & - \\
$1.0 \%$ & 162 & 12 & 7 & - & 5 \\
\hline
\end{tabular}

NPO: No. of plants observed; NMM: No. of morphological mutants; DM: Dwarf mutants; EFM: Early flowering mutants; TSM: Thornless stem mutants

\subsection{Chlorophyll mutants}

In the present investigation, nine different types of chlorophyll mutants were recorded in $M_{1} V_{1}$ generation for the different doses concentrations of $\gamma$-rays and EMS. Spectrum of chlorophyll mutations in $\mathrm{M}_{1} \mathrm{~V}_{1}$ generation is presented in Table 4. They are albina, albina green, xantha, chlorina, viridis, yellow viridis, striata, maculata and variegated type (Figure 3). Albina mutants were completely devoid of chlorophyll and could survive only a few days. Albina-green and yellow viridis had green white and yellow green leaves, respectively. Xantha had pale yellow coloured leaves and these mutants could not survive long due to disruption in chlorophyll

Out of the different types of mutants, maximum types (6) of chlorophyll mutants were observed at $7.5 \mathrm{~Gy}$-rays treatment followed by $5.0 \mathrm{~Gy}$ and $1.0 \%$ EMS treatments which had 5 types of chlorophyll mutants each. Among the mutagens, higher number of chlorophyll mutants were recorded in EMS than $\gamma$-ray treatments. Among the mutants recorded, chlorina 

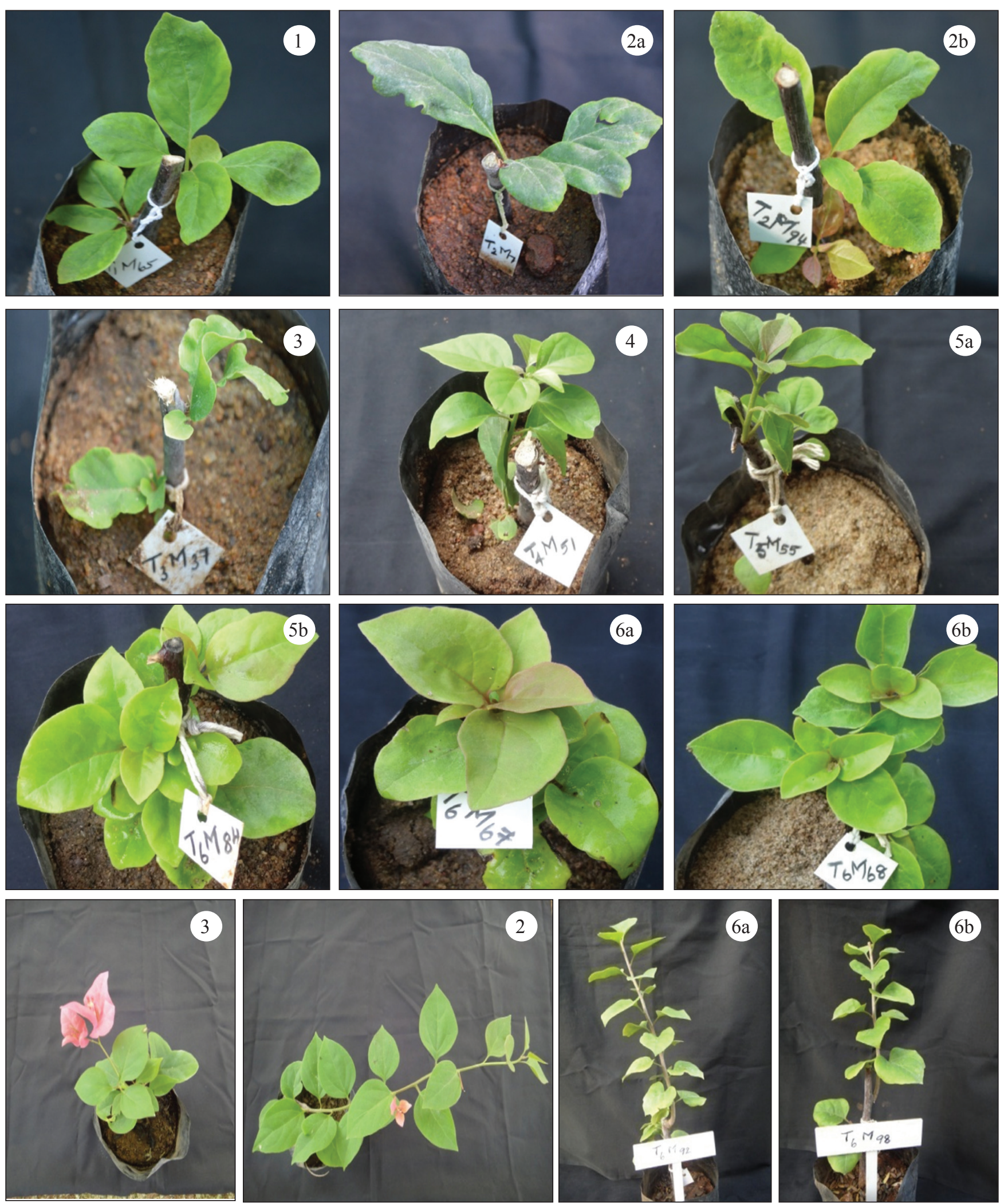

Early flowering mutant
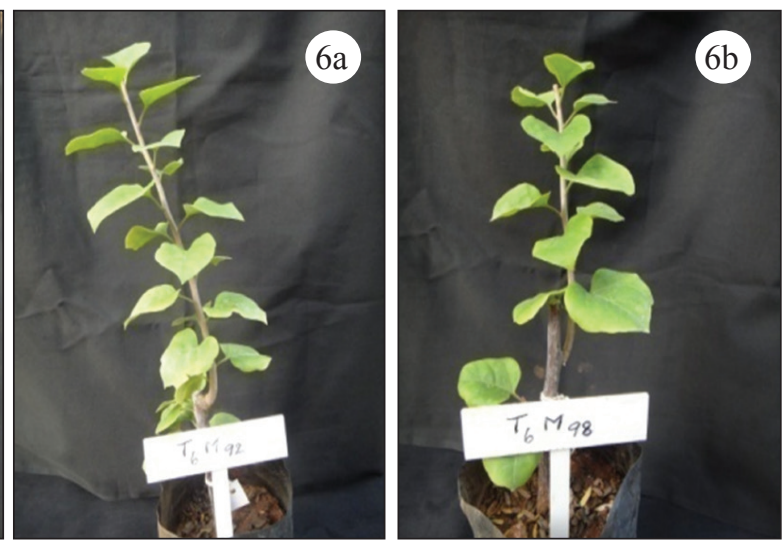

Thornless stem mutant

Dwarf mutants: 1: 5.0 Gy Gamma rays; 4: 0.8\% EMS; 2: 7.5 Gy Gamma rays; 5: 0.9\% EMS; 3:10.0 Gy Gamma rays; 6: 1.0\% EMS

Figure 2: Morphological Mutants of M1V1 generation in Bougainvillea cv. Lalbagh 


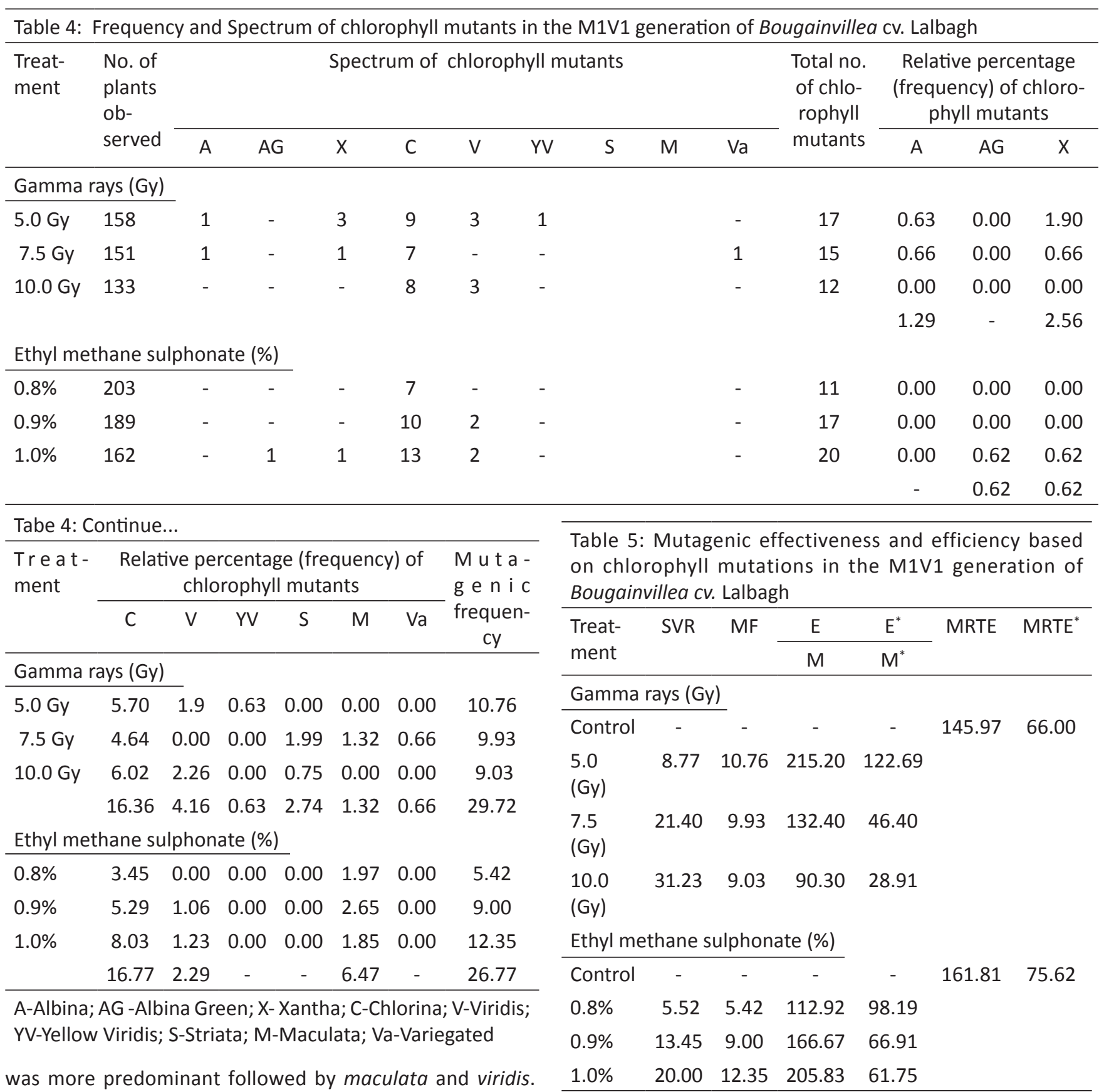

Chlorina was present in all the doses of the mutagens and was expressed at maximum frequency in all the mutagenic treatments, whereas albina green, yellow viridis and variegated type of mutants were rarely induced and its frequency was also less. Albina was observed with low frequency in $\gamma$-rays. Kolar et al. (2011) reported 11 types of chlorophyll mutants at varying frequencies in Delphinium malabaricum (Huth) Munz. with various mutagenic treatments. Higher frequency and a wider spectrum of chlorophyll mutants in chemical mutagen EMS have also been reported by Bhattacharya (2003) in carnation. The determination of mutagenic effectiveness involved the mutagenic frequency and levels of doses (Table 5). Mutagenic effectiveness was found to be higher (215.2)

SVR: \% survival reduction (L); MF: Mutation frequency (M); E: Effectiveness; $E^{*}$ : Efficiency; $M$ : $(M \times 100) G y^{-1}$ or $(C \times t) ; M^{*}$ : $(M \times 100) \mathrm{I}^{-1}$; MRTE: Mutation rate in terms of Effectiveness; MRTE*: Mutation rate in terms of Efficiency

in $\gamma$-irradiation at $5.0 \mathrm{~Gy}$, whereas in EMS treatment, it was higher (205.83) in 1.0\% concentration. The results of mutagenic effectiveness of EMS in carnation observed by Roychowdhury and Tah (2011) are in line with the present study. It was observed that the mutagenic efficiency was not proportional to the dose of mutagens. The maximum was 122.69 in 5.0 Gy $\gamma$-ray treatment and 98.19 in $0.8 \%$ of EMS. Similar results of mutation efficiency with lower dose of $\gamma$-ray 

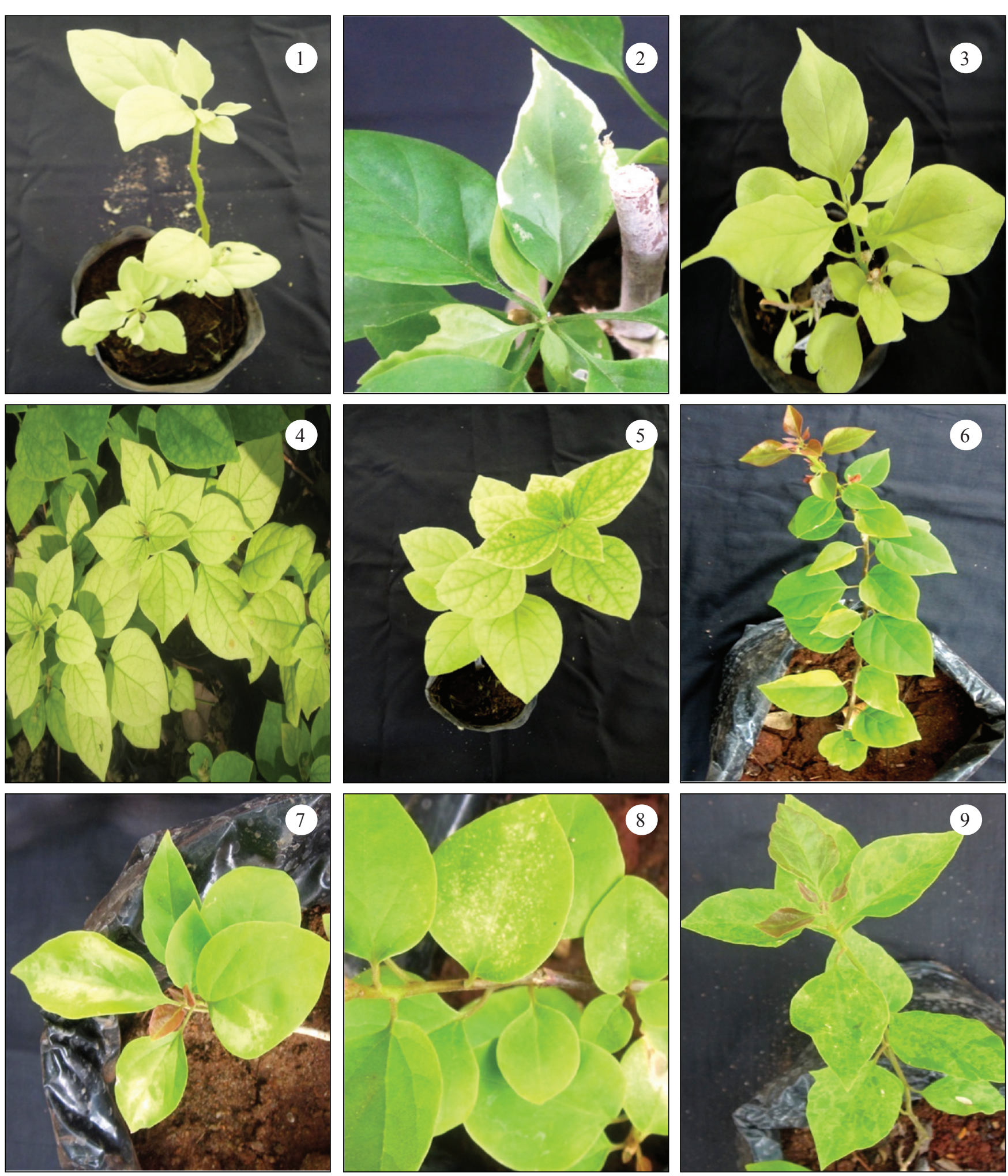

1: Albina; 2: Albina Green; 3: Xantha; 4: Chlorina; 5: Viridis; 6: Yellow Viridis; 7: Striata; 8: Maculata; 9: Variegated

Figure 3: Chlorophyll mutants observed in M1V1 generation of Bougainvillea cv. Lalbagh

were also reported by Padmadevi (2009) in chrysanthemum. In the present study, since the mutagens proved to be effective as well as efficient. The mutation rates were also calculated. Efficient mutagenesis is the production of desirable changes with minimum undesirable effects. In mutation breeding programmer, a high mutation rate accompanied 
by minimal deleterious effects is desirable. But generally the mutagen that gives the higher mutation rate also induces a high degree of lethality, sterility and other undesirable effects (Blixt et al., 1964). In this study, the mutation rates based on effectiveness and efficiency were found to be higher (161.81 and 75.62) respectively with respect to EMS when compared to 8 -irradiation.

\section{Conclusion}

$1.0 \% \mathrm{EMS}$ is more effective than other mutagenic treatments in inducing morphological mutations viz., dwarfness and thornlessness, whereas earliness in flowering was attained from 7.5 Gy and 10.0 Gy $\gamma$-rays. Among $\gamma$-ray and EMS treatments, higher dose of EMS (1.0\%) was more effective since it had induced higher number of chlorophyll mutations followed by $0.9 \%$ EMS and 5.0 Gy $\gamma$-rays. Chlorina type of mutant appeared at higher rates in all treatments over other types of chlorophyll mutants.

\section{Acknowledgement}

The authors sincerely thank the Department of Floriculture and Landscaping for the providing the planting material and the nursery space for raising the mutants. We also sincerely thank the Centre for Plant Breeding and Genetics, Tamil Nadu Agricultural University for providing the $\gamma$-Chamber.

The authors strongly acknowledge and are thankful to Dr. John Joel, Centre for Plant Breeding and Genetics, Tamil Nadu Agricultural University, Coimbatore for his timely suggestions during the research and in preparing the manuscript.

\section{References}

Amato, F., Ostenhof, O.H., 1956. Metabolism and spontaneous mutation in plants. Advances in Genetics 8, 1-22.

Banerji, B.K., Datta, S.K., 2002. Induction and analysis of $\gamma$ -rays-induced flower head shape mutation in 'Lalima' chrysanthemum (Chrysanthemum morifolium). Indian Journal of Agricultural Sciences 72(1), 6-10.

Bhattacharya, C., 2003. Effect of ethyl methanesulphonate on carnation (Dianthus caryophyllus L.). Environment and Ecology 21(2), 301-305.

Blixt, S., 1972. Mutation in Pisum. Agriculture and Horticultural Genetics 30, 1-293.

Blixt, S., Gelin, O., Mossberg, R., Ahnstrom, G., Ehrenberg, L., Lofgren, R.A., 1964. Studies of induced mutations in peas. IX. Induction of leaf spots in pea. Agriculture and Horticultural Genetics 22, 186-194.

Blixt, S., 1961. Quantitative studies of induced mutations in peas. V. Chlorophyll mutations. Agriculture and Horticultural Genetics 19, 1-402.

Datta, S.K., Banerji, B.K., 1993. >-ray induced somatic mutation in chrysanthemum cv. 'Kalyani Mauve'. Journal of Nuclear Agriculture and Biology 22(1), 19-27.

Datta, S.K., Banerji, B.K., 1997. Improvement of double bracted
Bougainvillea through $\gamma$-ray induced mutation. Frontiers in Plant Science 64, 395-400.

Dhivya, M., 2015. Studies on induced mutagenesis in crossandra (Crossandra infundibuliformis (L.) Nees). Ph.D. Thesis submitted to Tamil Nadu Agricultural University, Coimbatore.

Dilta, B.S., Sharma, Y.D., Gupta, Y.C., Bhalla, R., Sharma, B.P., 2003. Effect of $\gamma$-rays on vegetative and flowering parameters of chrysanthemum. Journal of Ornamental Horticulture 6, 328-334.

Etsuo, A., 2004. Practical suggestions for mutation breeding, Fukui Prefectural University, Forum for Nuclear Cooperation in Asia (FNCA) Mutation Breeding Project.

Fowler, D.B., MacQueen, K.F., 1972. Effects of low doses of $\gamma$ -radiation on yield and other agronomic characters of spring wheat (Triticum asetivum). Radiation Botany 12, 349-353.

Gaul, H., 1970. Mutagenic effects observable in the first generation plant injury and lethality. Manual Most Breed. 85-89, IAEA, Vienna.

Gordon, S.A., 1957. The effect of ionizing radiation on plantsBiochemical and physiological aspects. Quarterly Review of Biology 32, 3-14.

Gordon, S.A., 1956. The biosynthesis of natural auxins. In: The chemistry and mode of action of plant growth substances 65-75.

Gottschalk, W., Wolf, G., 1983. Induced mutations in plant breeding. Monographs on theoretical and applied genetics, Berlin, Springer Verlag 7, 238.

Gregory, W.C., 1966. X-ray breeding of peanuts (Arachis hypogea L.). Agronomy Journal 47, 396.

Gupta, M.N., Shukla, R., 1974. Mutation breeding in bougainvillea. Indian Journal of Genetics 34A.

Gustafson, A., 1940. The mutation system of the chlorophyll apparatus. Lunda Guv. Asskr. M.F. Adv., 2(11), 14.

Jain, S.M., 2010. Mutagenesis in crop improvement under the climate change. Romanian Biotechnological Letters 15(2), 89.

Kainthura, P., Srivastava, R., 2015. Induction of genetic variability and isolation of mutants in Tuberose (Polianthes tuberosa L). Tropical Agricultural Research 26(4), 721-732.

Kapadiya, D.B., Chawla, S.L., Patel, A.I., Ahlawat, T.R., 2014. Exploitation of variability through mutagenesis in Chrysanthemum (Chrysanthemum morifolium Ramat.) var. Maghi. The Bioscan 9(4), 1799-1804.

Kumari, K., Dhatt, K.K., Kapoor, M., 2013. Induced mutagenesis in Chrysanthemum morifolium variety 'Otome Pink' through $\gamma$-irradiation. The Bioscan 8(4), 1489-1492.

Kolar, F., Pawar, N., Dixit, G., 2011. Induced chlorophyll mutations in Delphinium malabaricum (Huth) Munz. Journal of Applied Horticulture 13(1), 18-24.

Konzak, C.F., Wagner, T., Foster, R.J., 1965. Efficient chemical 
mutagenesis, the use of induced mutations in Plant Breeding (Rep. FAO/IAEA Tech. Meeting Rome, 1964). Porgamon Press: 49-70.

Mahure, H.R., Choudhary, M.L., Prasad, K.V., Singh, S.K., 2010. Mutation in chrysanthemum through $\gamma$-irradiation. Indian Journal of Horticulture 67, 356-358.

Mekala, P., 2009. Improvement of Jasminum sambac cv. Gundumalli (Ait.) through mutation breeding. MSc. Thesis submitted to Tamil Nadu Agricultural University.

Misra, R.L., Bajpai, P.N., 1983a. A review on the mutation breeding of Gladiolus. Haryana Journal of Horticultural Sciences 12(3-4), 149-155.

Misra, R.L., Bajpai, P.N., 1983b. Effect of mutagens on shooting, leaf number, heading, plant height and spike length in gladioli. Indian Journal of Horticulture 40(1-4), 107-111.

Misra, P., Banerji, B.K., Anuj, K., 2009. Effect of $\gamma$-irradiation on chrysanthemum cultivar 'Pooja' with reference to induction of somatic mutation in flower colour and form.
Journal of Ornamental Horticulture 12(3), 213-216.

Padmadevi, K., 2009. In vivo and in vitro mutagenesis and molecular characterization in chrysanthemum (Dendranthema grandiflora Tzvelev). Ph. D. Thesis submitted to Tamil Nadu Agricultural University.

Ramesh, H.L., Yogananda Murthy, V.N., Munirajappa, P.V., 2012. Effect of $\gamma$-radiation on morphological and growth parameters of mulberry variety $M_{5}$. International Journal of Science and Nature 3(2), 447-452.

Roychowdhury, R., Tah, J., 2011. Assessment of chemical mutagenic effects in mutation breeding programme for $\mathrm{M}_{1}$ generation of Carnation (Dianthus caryophyllus). Research in Plant Biology 1(4), 23-32.

Sax, K., 1955. The effect of ionizing radiation on plant growth. American Journal of Botany 42, 360-364.

Sparrow, A.H., Evan, H.J.E., 1961. Nuclear factors affecting radio sensitivity I. The influence of size and structure. Brookhaven Sym. Biology (Chromosome complement and DNA content) 14, 76-100. 